\title{
Assessment of land use land cover and carbon sequestration in forests of Joida Taluk of Uttar Kannada district using Remote sensing technique
}

\author{
A. G. Koppad* \\ Department of Natural Resource Management, College of Forestry, Sirsi, University of Agricultural \\ Sciences, Dharwad-581401 (Karnataka), India \\ Pallavi P. Banavasi \\ Department of Natural Resource Management, College of Forestry, Sirsi, University of Agricultural \\ Sciences, Dharwad-581401 (Karnataka), India \\ Syeda Sarfin \\ Department of Natural Resource Management, College of Forestry, Sirsi, University of Agricultural \\ Sciences, Dharwad-581401 (Karnataka), India
}

${ }^{*}$ Corresponding author. Email: koppadag@uasd.in

\author{
Article Info \\ https://doi.org/10.31018/ \\ jans.v12i3.2317 \\ Received: July 8, 2020 \\ Revised: August 4, 2020 \\ Accepted: August 12, 2020
}

\section{How to Cite}

Koppad, A. G. et al. (2020). Assessment of land use land cover and carbon sequestration in forests of Joida Taluk of Uttar Kannada district using Remote sensing technique. Journal of Applied and Natural Science, 12(3): 344 - 348. https:// doi.org/10.31018/jans.v12i3.2317

\begin{abstract}
The study was conducted in Joida Taluk of Uttar Kannada district, Karnataka to assess the land use land cover (LULC) and carbon sequestration of the forest during the year 2019-20. The ground truth data for different LULC was collected using GPS, and data was used for classification of IRS LISS 4 data using maximum likelihood classifier in ERDAS imagine software. The sample plots of $23.2 \mathrm{~m} \times 23.2 \mathrm{~m}$ were laid out randomly in forests and growth parameters (tree height and diameter) were recorded, and biomass was estimated using the standard formula. There are eight LULC classes' viz., dense forest, moderately dense forest, open/sparse forest, scrub forest, agriculture, settlement, horticulture plantation and waterbody. The overall accuracy of the classification was $97.09 \%$. The total biomass in Joida Taluk from four forest classes (dense forest, moderately dense forest, open/sparse forest and scrub forest) was 44.16 million $\mathrm{m}^{3}$ and carbon sequestered was 15.57 million tonnes. The NDVI values ranging from -0.23 to 0.74 , indicating a higher value for dense forest. Based on this study, it is concluded that forests have potential in carbon sequestration, which in turn helps in mitigating the climate change.
\end{abstract}

Keywords: Carbon sequestration, Forest biomass, LULC, NDVI, Remote sensing

\section{INTRODUCTION}

Forest plays an important role in balancing the changes in the environment due to climate change (Koppad and Tikhile, 2013). It provides a wide range of economic and social benefits to humankind. In recent days, the forest is degrading due to various anthropogenic pressures which have become one of the reasons for climate change and global warming. Forests cover $30.6 \%$ of the Earth's landmass and its change has a large effect on biodiversity, clean air, water and carbon emissions (Gandhi et al., 2015). The assessment of carbon sequestration in the forest is necessary. The measuring and monitoring of carbon stock are important for sustainable forest uses (Csillik et al., 2019). Carbon sequestration is one of the most important forest ecosystem values as forest and forest soils have high potential to store carbon as compared to others (Cannell and Dewar, 1995).

Forest cover change can be monitored via remote sensing (RS) data (Lizhuang et al., 2018). The remote sensing data has many applications. One of the important applications is land use land cover classification (Koppad and Tikhile, 2014). Remote sensing technologies have a significant potential for mapping and extracting information about forest structure and biomass (Sinha et al., 2015). Normalised Difference Vegetation Index (NDVI) is one of the indices which help in assessing the vegetation pattern. Hence the experiment was conducted in Joida Taluk to assess the Lland use land cover classes (LULC), forest biomass estimation, carbon sequestration and to establish the regression equation between NDVI and wood volume. 


\section{MATERIALS AND METHODS}

The study was conducted in Joida Taluk of Uttar Kannada district which lies between $14^{\circ} 55^{\prime}$ to $15^{\circ} 30^{\prime} \mathrm{N}$ latitude and $74^{\circ} 15^{\prime}$ to $7440^{\prime} \mathrm{E}$ longitude having the area of $1,88,503$ hectares during the year 2019-20. The study area is shown in figure 1.

The LISS 4 data of February 2019 for Joida Taluk was procured from NRSC, Hyderabad. The LISS 4 data is used to assess the LULC classifications. The field survey was conducted, and the ground truth data in different land-use classes using GPS (GARMIN, OREGON 650) was collected. The NRSC data having three bands- blue, red and infrared were all layer stacked, and False Colour Composite (FCC) image was created. FCC image was clipped for the Joida taluka using shapefile in Arc GIS. FCC image of Joida taluka was processed in ERDAS imagine software for classification. The ground truth data collected from the field was used to locate the training sites for different land use classes in the image. For each of the classes training sites were selected, and the data were classified using Maximum Likelihood classifier using a supervised classification in ERDAS imagine software. After classification, the pixels which were miss-classified were merged to corresponding classes by confirming the actual classes through Google Earth. After merging all the miss classified pixels, true colours were assigned for each land use classes and their area was estimated.

The accuracy of classification was done by selecting training samples randomly over the entire study area. The training sites were tested with classes in the image and actual class using Google earth. The error matrix was prepared, and the overall accuracy of the supervised classification was done. Accuracy is considered to be the degree of closeness of results to the values accepted as true (Zavoianu et al., 2004). The aim of accuracy assessment is to quantitatively assess how effectively the pixels were sampled into the correct land cover classes (Wanga and Ndambuki, 2017). The error matrix is a square array of numbers which are arranged in rows and columns which show the values (i.e., pixels, clusters of pixels, or polygons) assigned to a particular category relative to the actual category as a verified table. Producer accuracy is a measure of how well real-world land cover types can be classified. This is a measure of omission error. User's accuracy is the total number of correct pixels in a category which is divided by a total number of pixels that were classified in that category; this result is called user's accuracy. It is indicative of the probability that a pixel classified on the map /image actually represents that category on the ground. This is also called as commission error (Congalton et al., 1999). The kappa coefficient is a measure of agreement or accuracy between the remote sensing derived classification map and the reference data. The Kappa coefficient, User accuracy and Producer accuracy for the different LULC classes were estimated. The final map was prepared in Arc GIS software. The LISS 4 data was also used to prepare the NDVI map in ERDAS software using NIR and Red bands. The overall accuracy, user's accuracy, producer's accuracy, and Kappa coefficient is calculated using the following formula.

Total number of correct classification

Overall accuracy $=\frac{\text { Total number of classification }}{\text { Tot }}$

$$
\text { User's accuracy }=\frac{\text { Number of correct classification }}{\text { Total number of classification in category (Row total) }}
$$

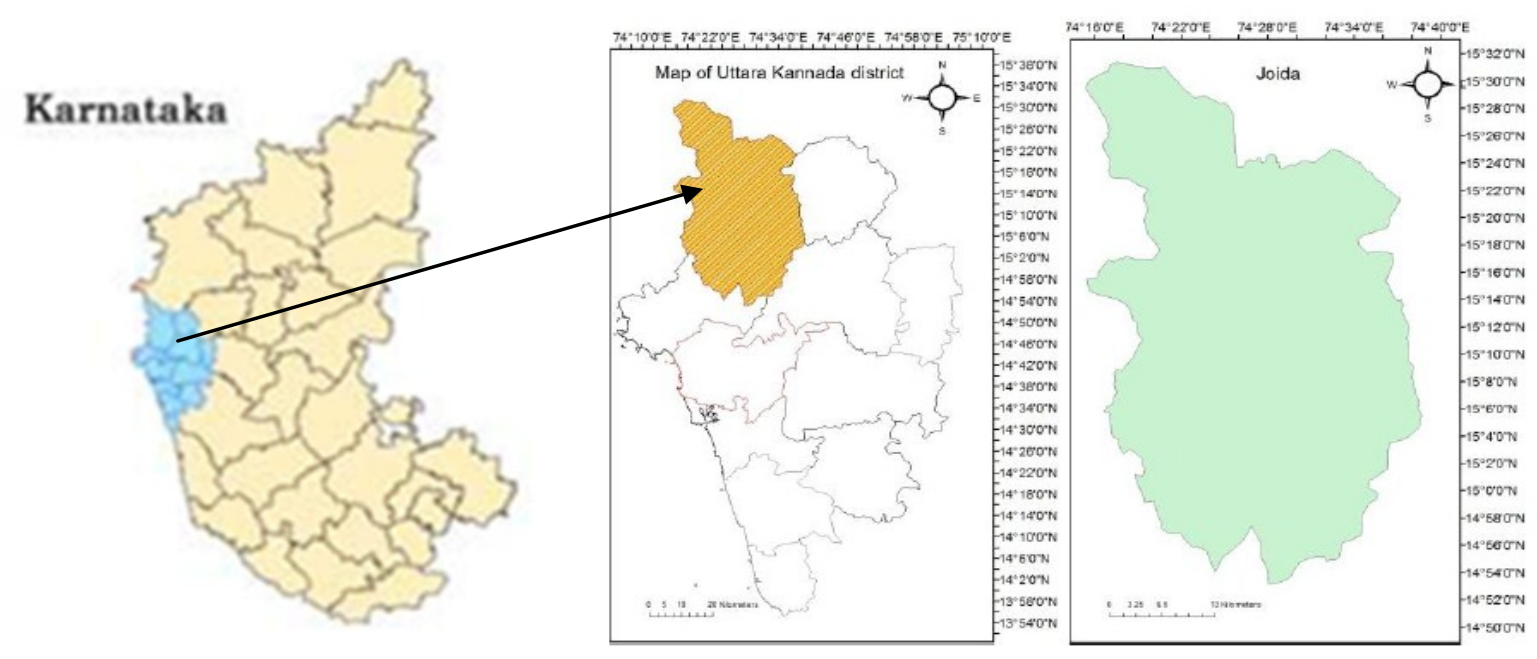

Fig.1. Study Area of Joida Taluk. 
Producer's accuracy $=\frac{\text { Number in the diagonal cell of error matrix }}{\text { Number in column total }}$ ..Eq.3

Kappa coefficient $=\frac{N A-B}{N^{2}-B}$

Where $\mathrm{N}=$ Total number of pixels

$A=$ Sum of correctly classified pixels

$B=$ Sum of the products of the column total and row total

The field transect survey was conducted in forests of different crown density classes such as very dense forest $(>70 \%$ crown density), moderately dense forest $(40-70 \%)$, open/sparse forest $(10-40 \%)$ and scrub forest $(<10 \%)$. Total of 20 plots were laid out. Each sample plot was $23.2 \mathrm{~m} \times 23.2 \mathrm{~m}$ Crown density was estimated using a Densitometer (Robert E. Lemmon, Forest densitometers). The tree species were identified by us in the field itself. The tree growth parameters such as diameter at breast height (dbh) and tree height were recorded using diameter tape and Ravi altimeter, respectively. In each plot, the tree species were also recorded. The wood volume was estimated using the standard formula. Wood sample of squareshaped was cut from each species and weighed in weighing balance, and also the volume of that squareshaped wood sample was calculated by using formulae volume of the cube

$$
\text { Density of wood }(\mathrm{g} / \mathrm{cc})=\frac{\text { Mass of wood sample }}{\text { Volume of that wood sample }}
$$

Based on the wood volume, amount of carbon sequestered in each of the forest density classes was estimated by standard formula. Based on the area assessed using LISS 4 data, the total biomass of Joida taluka was estimated according to the crown density classes (Rangaswamy and Nizalapur, 2008). Above-ground biomass (tonnes $/$ ha) $=$ Volume of tree $X$ Density of wood (Mac dicken, 1997) ................Eq.6 The above-ground biomass of standing trees was estimated to work out the amount of carbon sequestration by reducing the total biomass yield to its $50 \%$ or converting biomass by multiplying 0.5 (Mac Dicken., 1997).

Carbon sequestration (tonnes $/$ ha) $=$ Above-ground biomass (tonnes /ha) $\times 0.5$

\section{RESULTS AND DISCUSSION}

The results from the classified image indicated that the areas of LULC classes such as very dense forest (1, 17,472 ha), moderately dense forest (30,012 ha), open/sparse forest $(17,591 \mathrm{ha})$, scrub forest $(1,786$ ha), plantation (4319 ha), agriculture (4,572 ha), settlements (2,515 ha) and waterbody $(9,869$ ha) as shown in table 1. The important tree species identified are Terminalia tomentosa, Tectona grandis, Legaestremia lanceolata, Terminalia paniculata, Sygyzium cumini, and Ficus tsjahela. The average wood volume recorded in the very dense forest was 306.92 $\mathrm{m}^{3}$ per hectare, in the moderate dense forest was $194.65 \mathrm{~m}^{3}$ per hectare, in the sparse forest was 122.18 $\mathrm{m}^{3}$ per hectare and scrub forest it was $68.11 \mathrm{~m}^{3}$ per hectare. The total biomass estimated as per the LULC classes indicated that the very dense forest showed the total biomass of 25.42 million tonnes, moderately dense forest was 4.12 million tonnes, sparse/open forest was 1.52 million tonnes and scrub forest was 0.08 million tonnes. The LULC map of the study area is shown in Fig. 2. The similar results were obtained in the study conducted by Koppad and Janagoudar (2018) in Haliyal taluka of Uttara Kannada district.

The amount of carbon sequestered was found to be 12.71 million tonnes in very dense forest, 2.06 million tonnes in moderate dense forest, 0.76 million tonnes in sparse/open forest and 0.04 million tonnes in scrub forest. The total biomass in Joida Taluk from these four forest classes was 44.16 million $\mathrm{m}^{3}$ and carbon sequestered was 15.57 million tonnes (Table 1). The error matrix was created based on the sample site selected randomly for assessing the accuracy of the LULC classes it was indicated that the overall accuracy was $97.09 \%$ and the Kappa coefficient was 0.95 (Table 2). Forests have the potential to absorb $\mathrm{CO}_{2}$ from the atmosphere, which is stored as woody biomass (Pandey et al., 2019). The study carried out by

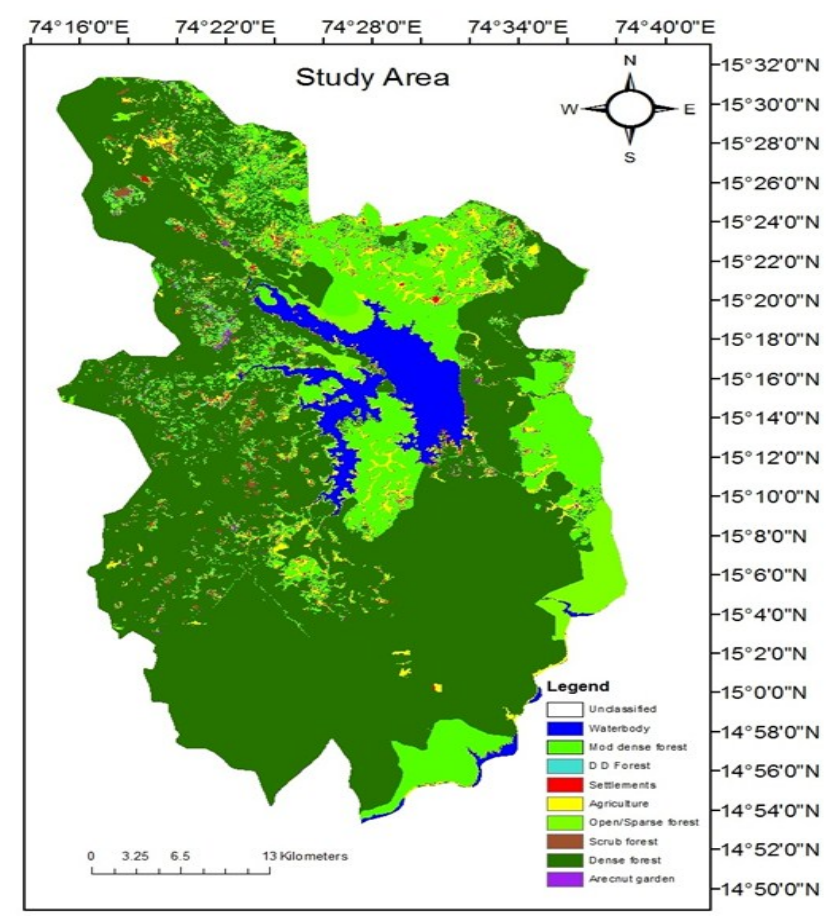

Fig. 2. LULC classification of Joida taluk of Uttara Kannada district. 
Table 1. Area and carbon sequestered in different LULC classes of Joida taluk.

\begin{tabular}{|c|c|c|c|c|c|c|c|}
\hline $\begin{array}{l}\text { SI. } \\
\text { No }\end{array}$ & LULC Classes & $\begin{array}{l}\text { Total } \\
\text { Area (ha) }\end{array}$ & $\begin{array}{l}\text { Area } \\
\text { in } \%\end{array}$ & $\begin{array}{l}\text { Average } \\
\text { (Volume } / \mathrm{m}^{3} / \mathrm{ha} \text { ) }\end{array}$ & $\begin{array}{l}\text { Biomass } \\
\left(\text { million } \mathrm{m}^{3}\right)\end{array}$ & $\begin{array}{l}\text { Biomass } \\
\text { (million } \\
\text { tonnes) } \\
\end{array}$ & $\begin{array}{l}\text { Carbon } \\
\text { sequestration } \\
\text { (million tonnes) }\end{array}$ \\
\hline 1 & Dense Forest & $1,17,472$ & 62.44 & 306.92 & 36.05 & 25.42 & 12.71 \\
\hline 2 & $\begin{array}{l}\text { Moderate Dense } \\
\text { Forest }\end{array}$ & 30,012 & 15.95 & 194.65 & 5.84 & 4.12 & 2.06 \\
\hline 3 & Sparse Forest & 17,591 & 9.35 & 122.18 & 2.15 & 1.52 & 0.76 \\
\hline 4 & Scrub Forest & 1,786 & 0.95 & 68.11 & 0.12 & 0.08 & 0.04 \\
\hline 5 & $\begin{array}{l}\text { Horticulture } \\
\text { Plantation }\end{array}$ & 4,319 & 2.29 & - & - & & - \\
\hline 6 & Agriculture & 4,572 & 2.43 & - & - & & - \\
\hline 7 & Waterbody & 9,869 & 5.25 & - & - & & - \\
\hline \multirow[t]{2}{*}{8} & Settlements & 2,515 & 1.34 & - & & & - \\
\hline & Total & $1,88,136$ & 100 & & 44.16 & 31.14 & 15.57 \\
\hline
\end{tabular}

Koppad and Malini (2019) shows that the dense forest has the highest area in Haliyal and Yellapur taluka of Uttara Kannada district. The study conducted in Simipal block, Bankura district, W. Bengal by Kiran and Srivastava (2014) shows the potential of LISS 4 data in land use land cover classification. The study shows the supervised classification accuracy of $90-95 \%$.

The NDVI map generated shows that the value ranging from -0.23 to 0.74 , indicating waterbody to very dense forest respectively. The other land use classes fall between these two values. Eight classes based on the NDVI value were created wherein the very dense forest has the value between $0.64-0.74$, moderately dense forest between $0.54-0.64$, sparse forest be-

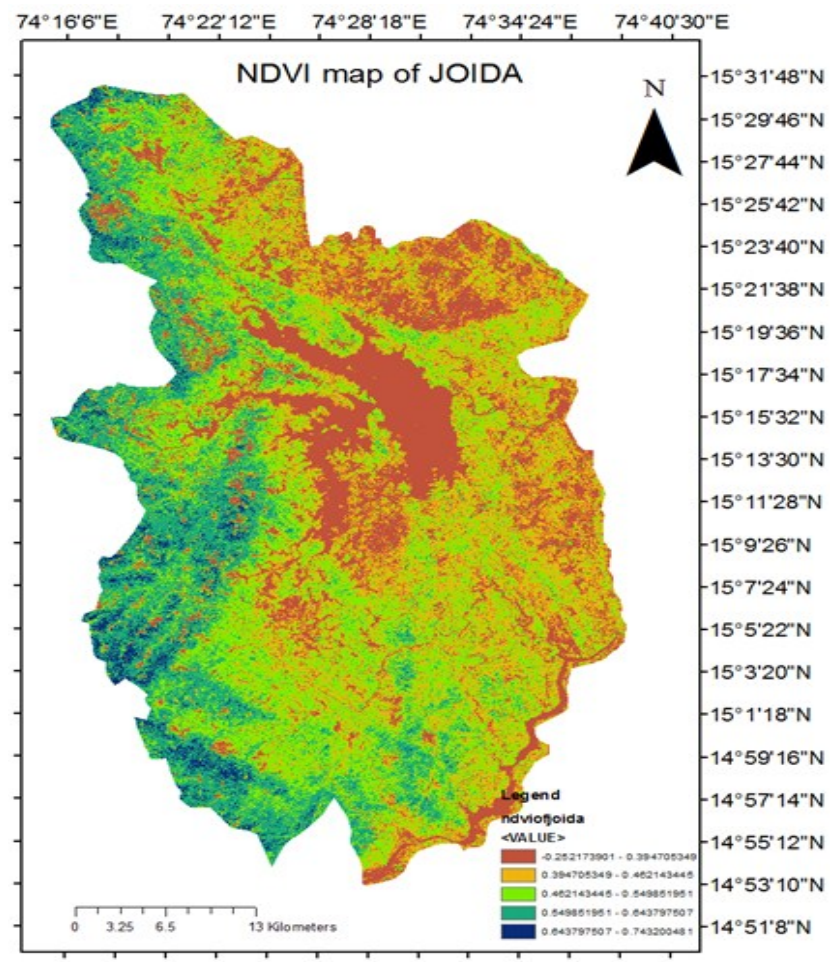

Fig. 3. NDVI map of Joida taluk of Uattar Kannada district. tween $0.46-0.54$ and scrub forest between 0.39 0.46 . Considering these four forest classes, the wood volume was estimated based on the sample plot survey for respective crown density classes of the forest. This was used with NDVI value to establish the regression equation. The equation obtained was $Y=$ 2072. $x$ - 900.1, where $Y$ is the dependent variable indicating wood volume and $x$ is the independent variable indicating NDVI value and the value of $R^{2}$ is 0.82 . The NDVI map of the study area is shown in Fig. 3.

\section{Conclusion}

It is concluded based on the study that there are 8 LULC classes in Joida taluka of Uttar Kannda district. Among different LULC classes, very dense forest covers $62.2 \%$ of the total area, which is most important for carbon sequestration in the present scenario of climate change. All the four crown density classes (dense forest, moderately dense forest, open/ sparse forest and scrub forest) of forest contribute the total carbon sequestration to the tune of 15.59 million tonnes. The NDVI map helps the forest department to identify the sites which are prone to forest degradation due to anthropogenic pressure. This, in turn, helps to protect the forest in future days. The study also supports making the policy decisions by the government with respect to the protection of the forest and increasing the green cover of the Joida taluk of Uttara Kannada district.

\section{REFERENCES}

1. Cannell, M. G. R. and Dewar, R. C. (1995). The carbon sink provided by plantation forests and their products in Britain. Forestry: An International Journal of Forest Research, 68 (1): 35 - 48. https://doi.org/10.1093/forestry/6 8.1.35.

2. Csillik, Ovidiu, Pramukta Kumar, Joseph Mascaro, Tara O'Shea, and Gregory P. Asner (2019). Monitoring tropical forest carbon stocks and emissions using Planet satellite data. Scientific Reports 9(1):1-12. doi.org/10.1038/ 
Table 2. Error Matrix of LULC classification.

\begin{tabular}{|c|c|c|c|c|c|c|c|c|c|c|}
\hline Classes & DF & MDF & OF & SF & HP & A & $\mathbf{W}$ & $\mathbf{S}$ & Total & $\begin{array}{l}\text { User } \\
\text { accuracy }\end{array}$ \\
\hline $\begin{array}{l}\text { Dense Forest } \\
\text { (DF) } \\
\text { Moderate }\end{array}$ & 170 & 0 & 0 & 0 & 0 & 0 & 0 & 0 & 170 & 100 \\
\hline $\begin{array}{l}\text { Dense Forest } \\
\text { (MDF) }\end{array}$ & 0 & 37 & 1 & & 0 & 0 & 1 & 0 & 39 & 94.87 \\
\hline $\begin{array}{l}\text { Open/Sparse } \\
\text { Forest (OF) }\end{array}$ & 0 & 0 & 13 & 0 & 0 & 0 & 0 & 0 & 13 & 100 \\
\hline $\begin{array}{l}\text { Scrub Forest } \\
\text { (SF) } \\
\text { Horticulture }\end{array}$ & 0 & 0 & 0 & 7 & 0 & 0 & 1 & 3 & 11 & 63.63 \\
\hline $\begin{array}{l}\text { Plantation } \\
\text { (HP) }\end{array}$ & 0 & 0 & 0 & 0 & 10 & 0 & 0 & 0 & 10 & 100 \\
\hline Agriculture $(A)$ & 0 & 2 & 0 & & 0 & 6 & 0 & 0 & 8 & 75 \\
\hline $\begin{array}{l}\text { Waterbody } \\
\text { (W) }\end{array}$ & 0 & 0 & 0 & 0 & 0 & 0 & 16 & 0 & 16 & 100 \\
\hline $\begin{array}{l}\text { Settlements } \\
\text { (S) }\end{array}$ & 0 & 0 & 0 & 0 & 0 & 0 & 0 & 8 & 8 & 100 \\
\hline Total & 170 & 39 & 14 & 7 & 10 & 6 & 18 & 11 & 275 & \\
\hline $\begin{array}{l}\text { Producer } \\
\text { accuracy }\end{array}$ & 100 & 94.9 & 92.8 & 100 & 100 & 100 & 88.9 & 72.7 & & \\
\hline & \multicolumn{10}{|c|}{ Over all accuracy $=\mathbf{9 7 . 0 9} \%$} \\
\hline
\end{tabular}

s41598-019-54386-6.

3. Congalton, Russell G. (2001). Accuracy assessment and validation of remotely sensed and other spatial information. International Journal of Wildland Fire, 10(4): 321328. DOI: 10.1071/WF01031.

4. Gandhi, G., Meera, S., Parthiban, Thummalu, N. and Christy, A. (2015). NDVI: Vegetation change detection using remote sensing and GIS - A case study of Vellore District. Procedia Computer Science, 57: 1199-1210. doi.org/10.1016/j.procs.2015.07.415.

5. Koppad, A. G., and Tikhile, P. (2013). Influence of land use land cover classes on carbon sequestration in soils of Sirsi and Siddapur taluka of Uttara Kannada District, India. International Journal of Current Research., 5 (4): 1012-1015.

6. Koppad, A. G., and Tikhile, P. (2014). Role of forest on carbon sequestration in soils of Joida and Karwar taluka of Uttara Kannada district. Indian Forester, 140 (3): 260-264.

7. Koppad, A.G., and Janagoudar, B. S. (2018). Effect of Land Use Land Cover on Soil Carbon Sequestration in Haliyal Taluka of Uttara Kannada District. Indian Forester 144, 3: 234-237.

8. Koppad, A.G., and Malini P J. (2019). Assessment Of Land Use Land Cover Classification And Water Resource Impact On Forest Productivity And Carbon Sequestration In Yellapur And Haliyal Taluka Of Uttara Kannada District, Karnataka, India Through Geoinformatics Approach. International symposium on applied Geoinformatics 1(1):59-63.

9. Kiran, V. S. S., Y. K. Srivastava, and M. Jagannadha Rao. (2014). Utilization of Resources at LISS IV Data for Infrastructure Updation and Land Use/Land Cover Mapping-A Case Study from Simlipal Block, Bankura District, W. Ben- gal." International Journal of Advance Remote Sensing GIS 3 (1): 592-597.

10.Lizhuang, L., Chen, F., Shi, L. and Niu, S. (2018). NDVI derived forest area change and its driving factors in China. PloS one, 13: 10. doi.org/10.1371/journal.pon e.020 588

11.MacDicken, Kenneth $G$ (1997). A guide to monitoring carbon storage in forestry and agroforestry projects. Forest Carbon Monitoring Program.1-87.

12.Madugundu, Rangaswamy, Vyjayanthi Nizalapur, and Chandra Shekhar Jha (2008). "Estimation of LAI and above-ground biomass in deciduous forests: Western Ghats of Karnataka, India." International Journal of Applied Earth Observation and Geoinformation 10(2):211219. doi:10.1016/j.jag.2007.11.004.

13.Pandey, P. C., Prashant, K., Srivastava, Chetri, T., Choudhary, B. K. and Kumar, P. (2019). Forest biomass estimation using remote sensing and field inventory: A case study of Tripura, India. Canadian Journal of Remote Sens., 32(5): 355-366. doi: 10.1007/s10661-019-7730-7.

14.Sinha, S., Jeganathan, C., Sharma, L. K. and Nathawat, M. S. (2015). A review of radar remote sensing for biomass estimation. International Journal of Environmental Science and Technology., 15(12): 1779-1792.

15.Rwanga, Sophia S., and Julius M. Ndambuki (2017). "Accuracy assessment of land use/land cover classification using remote sensing and GIS." International Journal of Geoscience,s 8(04):611. doi.org/10.4236/ijg.2017.8 4033.

16.Zavoianu, F., Caramizoiub, A. and Badeaa, D. (2004). Study and accuracy assessment of remote sensing data for environmental change detection in Romanian coastal zone of the Black Sea. Proceeding of ISPRS, pp. 778-783. 